\title{
Association between Blood Pressure and Quality of Life of Patients with Diabetes Mellitus Type 2 in the Bogor City Indonesia
}

\author{
Nikson Sitorus ${ }^{1}$, Oster Suriani ${ }^{1}$, Indri Yunita Suryaputri ${ }^{1}$, Fredrick Dermawan Purba ${ }^{2}$, Aprizal Satria Hanafi $^{3}$ \\ ${ }^{1}$ National Institute of Health Research and Development, Centre for Research and Development of Public Health Efforts, \\ Ministry of Health, Jakarta, Indonesia; ${ }^{2}$ Department of Developmental Psychology, Faculty of Psychology, Universitas \\ Padjajaran, Bandung, Indonesia; ${ }^{3}$ Department of Epidemiology, Alumnus of Master of Epidemiology Student, School of Public \\ Health, University of Indonesia, Depok, Indonesia
}

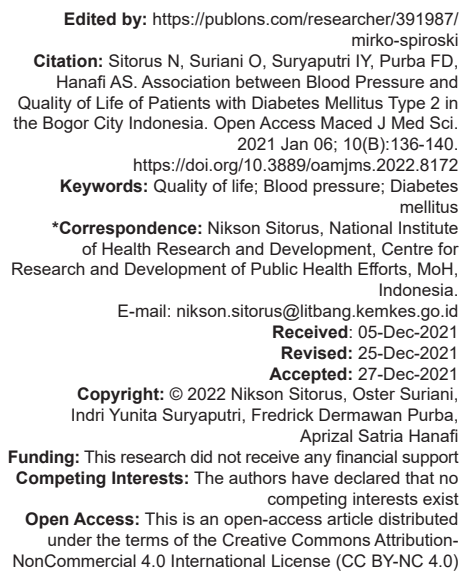

\section{Introduction}

In 2014, according to the WHO, there were 422 million adults over the age of 18 who lived with diabetes mellitus (DM) [1]. The prevalence of DM in Indonesia tends to increase, from $5.7 \%$ in 2007 to $6.9 \%$ in 2013 , and increase again to $8.5 \%$ and $10.9 \%$ in 2018 [2], [3], [4], [5]. Indonesia is the $4^{\text {th }}$ country with the highest prevalence of DM in the world. The WHO data estimates that the number of people with DM Type 2 in Indonesia will increase significantly to 21.3 million by the next 2030 [6].

From 2011 until now in the Bogor City a cohort study of Non-Communicable Diseases has been conducted by the National Institute of Health Research and Development, Ministry of Health RI. The results of the initial screening cohort study in 2011 found $174(3.1 \%)$ DM patients who had been diagnosed by health workers from 5680 residents, and for 4 years there were 795 DM incidents [7]. Based on these data it can be seen that the prevalence of DM patients increases every year in Indonesia and the relationship between blood pressure and quality of life (QoL) of patients with DM Type 2 has not been known in Bogor City in 2018.

A study from Daher et al. (2015) states that hypertension is factor that affects physical function directly so that it will affect the QoL of people with type 2 DM [8]. Other studies from Yiming also mentioned that hypertension is one of the factors that influence the QoL of people with type 2 DM [9], [10].

Based on previous studies, further study is needed to see the effect of blood pressure and QoL of people with type $2 \mathrm{DM}$ and many studies of the QoL of people with DM carried out in hospital settings, whereas in this study was carried out in community settings by visiting patients' homes directly. This study aims to find a relationship between blood pressure and QoL of people with DM type 2 by controlling other variables such as age, sex, married, education, employment, and therapy for DM performed. 


\section{Methods}

The study design in this study is crosssectional. The population is all DM patients who have become community-based participants in the NCDs Cohort Study, with inclusion criteria namely DM patients who have been diagnosed by doctors with DM Type 2 from 2011 to 2017 as the results of a cohort study, aged $>25$ years and willing to follow study and fulfill exclusion criteria, i.e., DM patients who cannot communicate verbally or have disabilities, women who are pregnant and patients who are hospitalized

The sampling technique was done by Systematic Random Sampling and the results of 114 samples were obtained. The variable in this study is blood pressure, age, sex, education, occupation, marital status, therapy, and QoL. Instruments for measuring blood pressure using sphygmomanometer and for measuring QoL using a modified DM QoL questionnaire with 30 items of questions [9] and other variables using a structured questionnaire.

Data collection was carried out using interview techniques directly in the respondent's house. Data collectors were carried out by trained researchers and enumerators after the perception was done between data collectors. Data analysis was performed by univariate, bivariate analysis with Chi-square and simple logistic regression and multivariate analysis using multiple logistic regression with significance level at $5 \%$. Data processing was carried out with the help of Statistical Product and Service Solutions (SPSS) programs. This study has received Ethical Approval from the National Institute of Health Research and Development Commission for Health Research Ethics with Number LB.02.01/2/KE.224/2018.

\section{Results}

This study was carried out among 144 DM patients who met the inclusion criteria during the period 2011-2017 in Bogor City, the description of the study subjects can be seen in Table 1.

Table 1 shows that of the 114 people who were research subjects, 2/3 had hypertension, most of them were adults (25-60 years old), female, had low education ( $\leq$ SMA) and $2 / 3$ had DM (Table 1). Understanding of the QoL in this study is perception or subjective views of DM patients on perceived satisfaction, both to physical abilities (daily activities, rest and sleep), psychological (self-image of body image and appearance), social relationships (social support and sexual activity), and environment (health environment, opportunities for information and skills, recreation opportunities and free time). To determine the QoL of people with DM whether
Table 1: Characteristic distribution of DM type 2 patients in Bogor city in 2018

\begin{tabular}{lll}
\hline Variable & $\mathrm{n}$ & Percentage \\
\hline Blood pressure & & \\
$\quad$ Not hypertension & 46 & 31.9 \\
$\quad$ Hypertension & 98 & 68.1 \\
Age & & \\
$\quad$ Adult age (25-60 years) & 100 & 69.4 \\
$\quad$ Elderly (>60 years) & 44 & 30.6 \\
Sex & & \\
$\quad$ Male & 29 & 20.1 \\
$\quad$ Female & 115 & 79.9 \\
Education & & \\
2 High school (High) & 54 & 37.5 \\
$\quad$ High school (Low) & 90 & 62.5 \\
Occupation & & \\
$\quad$ Working & 49 & 34.0 \\
$\quad$ Not working & 95 & 66.0 \\
Existence of Spouse & & \\
$\quad$ Yes & 112 & 77.8 \\
$\quad$ No & 32 & 22.2 \\
Therapy & & \\
$\quad$ Getting treatment & 109 & 75.7 \\
$\quad$ Not getting treatment & 35 & 24.3 \\
QoL & & \\
$\quad$ Good & 72 & 50.0 \\
$\quad$ Not good & 72 & 50.0 \\
Total & 144 & 100 \\
\hline
\end{tabular}

good or not good is range of answer score question is $30-150$, with using a median as a cut off 114.5 obtained $50 \%$ good and $50 \%$ not good.

The results of bivariate analysis showed that the variables that were significantly related $(p<0.05)$ to the QoL of people with DM type 2 were blood pressure $(O R=0.35)$, education $(O R=3.42)$, and the presence of spouse $(\mathrm{OR}=2.73)$ while other variables were not related statistically $(p>0.05)$ (Table 2$)$.

The results of the assessment of QoL showed, $58.2 \%$ of patients with DM who had hypertension, and $32.6 \%$ of those without hypertension had good QoL. Half of study subjects who were in the adult age category and $47 \%$ with female sex, had a good QoL. QoL based on education shows $68.5 \%$ with the category of higher education having a good QoL.

Assessment of QoL for occupational categories, 95 people with DM who working, 59.2\% of them have a good QoL. There was spouse of 112 respondents, $55.4 \%$ of them with good QoL. We also found DM patients who received treatment, $53.2 \%$ of them had good QoL, and only $40 \%$ of people with DM who did not get treatment that had good QoL (Table 2).

In Table 3, we can see the effect of independent variables with non-adjusted and adjusted variables. In the full model the highest influence was education ( $p<0.05$, OR: 3.662) while the blood pressure is protective factor $(p<0.05, O R=0.293)$.

The final model of multivariate analysis of QoL, logistic regression equation model was obtained to determine the factors that most influence QoL. From several stages that were passed in the backward model that issues one by one the variables that were considered less influential start from the smallest influence. From the final results of logistic regression, the variables with the highest influence on QoL were obtained from education $(\mathrm{OR}=3.63, \mathrm{Cl}$ : 1.69-7.78) 
Table 2: Analysis of the relationship of blood pressure and confounding variables to the quality of life of patients with DM type 2 in Bogor city

\begin{tabular}{|c|c|c|c|c|c|c|c|c|}
\hline \multirow[t]{3}{*}{ Variable } & \multicolumn{4}{|c|}{ Quality of life } & \multirow{2}{*}{\multicolumn{2}{|c|}{ Total }} & \multirow[t]{3}{*}{$p$-value } & \multirow[t]{3}{*}{ OR $(95 \% \mathrm{Cl})$} \\
\hline & \multicolumn{2}{|c|}{ Good } & \multicolumn{2}{|c|}{ Not Good } & & & & \\
\hline & $\mathrm{n}=72$ & $\%$ & $\mathrm{n}=72$ & $\%$ & $n=144$ & $\%$ & & \\
\hline \multicolumn{9}{|l|}{ Blood pressure } \\
\hline Not hypertension & 15 & 32.6 & 31 & 67.4 & 46 & 100 & \multirow{2}{*}{0.005} & \multirow{2}{*}{$0.35(0.18-0.73)$} \\
\hline Hypertension & 57 & 58.2 & 41 & 41.8 & 98 & 100 & & \\
\hline \multicolumn{9}{|l|}{ Age } \\
\hline Adult age (25-60 years) & 52 & 52.0 & 48 & 48.0 & 100 & 100 & \multirow[t]{2}{*}{0.470} & \multirow[t]{2}{*}{$1.3(0.64-2.65)$} \\
\hline Elderly (>60 years) & 20 & 45.5 & 24 & 54.5 & 44 & 100 & & \\
\hline \multicolumn{9}{|l|}{ Sex } \\
\hline Male & 18 & 62.1 & 11 & 37.9 & 29 & 100 & \multirow[t]{2}{*}{0.149} & \multirow[t]{2}{*}{$1.85(0.80-4.26)$} \\
\hline Female & 54 & 47.0 & 61 & 53.0 & 115 & 100 & & \\
\hline \multicolumn{9}{|l|}{ Education } \\
\hline 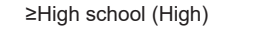 & 37 & 68.5 & 17 & 31.5 & 54 & 100 & \multirow[t]{2}{*}{0.001} & \multirow[t]{2}{*}{$3.42(1.67-6.98)$} \\
\hline sHigh school (Low) & 35 & 38.9 & 55 & 61.1 & 90 & 100 & & \\
\hline \multicolumn{9}{|l|}{ Occupation } \\
\hline Working & 29 & 59.2 & 20 & 40.8 & 49 & 100 & \multirow[t]{2}{*}{0.115} & \multirow[t]{2}{*}{$1.75(0.87-3.52)$} \\
\hline Not working & 43 & 45.3 & 52 & 54.7 & 95 & 100 & & \\
\hline \multicolumn{9}{|l|}{ Existence of spouse } \\
\hline Yes & 62 & 55.4 & 50 & 44.6 & 112 & 100 & \multirow[t]{2}{*}{0.019} & \multirow[t]{2}{*}{$2.73(1.18-6.29)$} \\
\hline No & 10 & 31.2 & 22 & 61.8 & 32 & 100 & & \\
\hline \multicolumn{9}{|l|}{ Therapy } \\
\hline Getting treatment & 58 & 53.2 & 51 & 46.8 & 109 & 100 & \multirow[t]{2}{*}{0.176} & \multirow[t]{2}{*}{$1.71(0.79-3.70)$} \\
\hline Not getting treatment & 14 & 40.0 & 21 & 60.0 & 35 & 100 & & \\
\hline
\end{tabular}

Table 3: Multivariate analysis of the relationship of blood pressure to the QoL of patients with DM type 2 in Bogor city in 2018

\begin{tabular}{|c|c|c|c|c|c|c|c|c|c|c|}
\hline \multirow[t]{2}{*}{ Variable } & \multicolumn{2}{|c|}{ Full model } & \multicolumn{2}{|c|}{ Without age } & \multicolumn{2}{|c|}{ Without sex } & \multicolumn{2}{|c|}{$\begin{array}{l}\text { Without } \\
\text { occupation }\end{array}$} & \multicolumn{2}{|c|}{$\begin{array}{l}\text { Without } \\
\text { therapy }\end{array}$} \\
\hline & $\mathrm{p}$ & OR & $\mathrm{p}$ & OR & $\mathrm{p}$ & OR & $p$ & OR & $\mathrm{p}$ & OR \\
\hline Blood pressure & 0.003 & 0.293 & 0.003 & 0.294 & 0.004 & 0.298 & 0.003 & 0.292 & 0.002 & 0.282 \\
\hline Age & 0.875 & 0.935 & - & & - & & - & & - & \\
\hline Sex & 0.747 & 0.842 & 0.770 & 0.86 & - & & - & & - & \\
\hline Spouse & 0.051 & 2.618 & 0.050 & 2.57 & 0.052 & 2.51 & 0.043 & 2.58 & 0.035 & 2.66 \\
\hline Education & 0.001 & 3.662 & 0.001 & 3.62 & 0.001 & 3.58 & 0.001 & 3.73 & 0.001 & 3.63 \\
\hline Occupation & 0.400 & 1.426 & 0.404 & 1.42 & 0.434 & 1.36 & - & & - & \\
\hline Therapy & 0.292 & 1.612 & 0.292 & 1.61 & 0.302 & 1.59 & 0.319 & 1.56 & - & \\
\hline
\end{tabular}

and the blood pressure is protective factor $(\mathrm{OR}=0.282$, Cl: 0.13-0.63) (Table 4).

Table 4: Multivariate final model

\begin{tabular}{lllllll}
\hline Variable & $\mathrm{B}$ & $\mathrm{SE}$ & Wald & $\mathrm{P}$ value & $\mathrm{OR}$ & $95 \% \mathrm{Cl}$ \\
\hline Blood pressure & -1.264 & 0.412 & 9.393 & 0.002 & 0.282 & $0.13-0.63$ \\
Existence of spouse & 0.977 & 0.463 & 4.446 & 0.035 & 2.66 & $1.07-6.59$ \\
Education & 1.289 & 0.390 & 10.937 & 0.001 & 3.63 & $1.69-7.78$ \\
Constant & -0.148 & 0.392 & 0.142 & 0.706 & 0.862 & \\
\hline
\end{tabular}

\section{Discussion}

The QoL of DM patients in this study has a balanced number between DM patients with good and poor QoL. Statistically, the variables of blood pressure, education and the existence of spouse have a significant relationship to the QoL.

The starting point for healthy living with DM is an early diagnosis, the longer a person lives with undiagnosed and untreated DM, the worse the health outcome. For those diagnosed with DM, a series of interventions can reduce the risk of bad DM, regardless of what type of DM they may have. These interventions include blood pressure control, blood glucose, through a combination of diet, physical activity and, if necessary treatment, to facilitate early treatment [1].
Our study shows that most people with DM have hypertension. The majority of DM patients are female. This is in line with several other studies that show that women suffer the most from DM [11], [12], [13], [14]. Most study subjects have low education and do not work. Our study also shows that generally people with DM have grown up and married. This result is in line with several other studies on DM [15], [16], [17]. People who know they are sick, most of them will surely seek treatment, this is precisely what causes most of the study respondents to get DM treatment [13], [18].

In general, the QoL of DM patients in our study is balanced, between the QoL of good and poor. Different results were reported in several other studies, where DM patients tend to have a poor QoL [16], [19]. This might occur because of differences in the study locus. The study we conducted is community-based, where our sample is not at a health facility to undergo treatment, in contrast to several studies that base study on patients who are undergoing DM care at health care facilities [17], [20].

In bivariate analysis, we found variables of blood pressure, education and the existence of spouse had a significant relationship to QoL while age, sex, occupation, and therapy variables were not statistically related, the results of other studies that assessed demographic variables on the QoL of DM patients also reported the same thing [15], [17], [21].

Hypertension occurs in more than two-thirds of patients with DM type 2 [22], [23]. Multivariate analysis of the effect of pressure on QoL, OR value of blood pressure did not decrease or increase by more than $10 \%$, this indicates that the influence of blood pressure on QoL is relatively stable (Table 3). DM patients who do not suffer from hypertension are protective factors against poor QoL. This means that DM patients who do not suffer from hypertension will have a greater possibility of obtaining a good QoL. Other studies also show consistent results, where DM patients who have hypertension tend to have a poor QoL [23], [24]. 
Treating hypertension in diabetic patients can reduce mortality, stroke risk, and cardiovascular disease events [25], [26]. Treating hypertension provides a similar relative risk reduction in patients with or without $\mathrm{DM}$, but carries a greater absolute risk in patients with DM due to a greater initial risk [25], [27]. A number of other studies also show a close relationship between DM and hypertension [28]. DM causes difficult hypertension to be treated, on the other hand, high blood pressure makes the impact of DM more dangerous. Patients with DM type 2 have a prevalence of high blood pressure compared to ordinary DM patients [28], [29]. Blood pressure control is one of the interventions that can reduce the risk of bad DM [30].

The results of our study show a strong relationship between education and the QoL of people with DM. The final model of multivariate analysis of QoL shows that the most influential variable in QoL is education. People with DM who have a low level of education tend to have a poor QoL. Education, in this case, is related to knowledge, patients who are highly educated can develop coping mechanisms and a good understanding of information. Other studies also show similar things where a good QoL in people with DM tends to be found in patients with higher levels of education [16], [21]. Education is an important factor in understanding disease, self-care, and controlling blood sugar, including controlling blood pressure. High levels of education were positively related to the QoL of people with DM [23], [31]. So that the education factor is one of the factors that can affect the QoL of a DM patient [14], [15], [32].

The existence of a spouse can have a positive impact on the treatment of DM, partner support with adherence in undergoing the treatment process in DM patients significantly improves the QoL for people with DM [17], [33]. Other study shows that DM patients who married tend to have a better QoL than not having a spouse [21], [32], [33]. The form of attention from a partner will improve the self-care of DM Type 2 patients who can reduce the risk of complications. Partner support such as reminding and monitoring food according to recommendations, helping in terms of treatment, and providing information is one of the things that affect the high QoL of patients with DM Type 2.

This study has limitations because this is a cross-sectional study, so it cannot determine causal relationships. Longitudinal studies are needed to assess the natural history of DM, disease complications, and QoL to draw strong conclusions about the causal pathways of this association.

The QoL of DM patients in this study was almost balanced between DM patients with good and bad QoL. Statistically, the variables of blood pressure, education, and the presence of a partner have a significant relationship with the QoL of DM patients.

\section{Author's Contribution}

NS is main contributor. OSS, IYS, FDP, and ASH are member contributor. Conceptualization: NS. Data collection: NS, OSS, IYS. Formal analysis: NS, ASH. Methodology: NS, OSS, IYS. Writing-original draft: NS, ASH. Writing-review \& editing: NS, OSS, IYS, FDP, ASH. All authors approved the final version of the manuscript.

\section{Acknowledgment}

Thanks to Head of National Institute of Health Research and Development RI, Head of Centre for Research and Development of Public Health Efforts, PPI Centre for Research and Development of Public Health Efforts, Health Office of Bogor City, Sudirham, All Head of Central Bogor Sub-District, and people with DM who were respondents to the study.

\section{References}

1. World Health Organization. Global Report on Diabetes. Geneva: World Health Organization; 2014 Available from: https://apps.who.int/iris/bitstream/ handle/10665/204871/9789241565257_eng.pdf;jsessionid= 58FB19153D48798699A14CEBD67E62B1? sequence=1 [Last accessed on 2020 Jun 02].

2. Ministry of Health RI. Basic Health Research (Riset Kesehatan Dasar). Jakarta: National Institute of Health Research and Development; 2007.

3. Ministry of Health RI. Basic Health Research (Riset Kesehatan Dasar). Jakarta: National Institute of Health Research and Development; 2013.

4. Ministry of Health RI. Riskesdas in Number West Java Province 2013. Jakarta: National Institute of Health Research and Development; 2013.

5. Ministry of Health RI. Basic Health Research (Riset Kesehatan Dasar). Jakarta: National Institute of Health Research and Development; 2018.

6. Siena I. The Number of Diabetics in Indonesia is Astounding Yayasan Sinergi Muda Indonesia; 2017. Available from: https:// mudazine.com/ibnusie/penderita-diabetes [last accessed on 2019 Mar 09].

7. Pradono J, Rahajeng E, Oemiati R. Cohort Study of Risk Factors for Non-Communicable Diseases and Child Growth in 2016; 2017. Available from: http://perpustakaan.litbang.depkes. go.id [Last accessed on 2020 Jul 10].

8. Daher AM, AIMashoor SA, Winn T. Glycaemic control and quality of life among ethnically diverse Malaysian diabetic patients. Qual Life Res. 2015;24(4):951-8. https://doi.org/10.1007/ s11136-014-0830-5 PMid:25352036

9. Yiming L. Survey and analysis on factors affecting living quality of Type 2 diabetes. Anhui Med J. 2009;30(7):748-50. 
10. Tyas MDC. Correlation Self Care and Illness Perception with Quality of Life Patients DM Type 2 in Nursing Care Context at Blitar. Thesis: Depok Faculty of Public Health Universitas Indonesia; 2008.

11. Javanbakht M, Abolhasani F, Mashayekhi A, Baradaran HR, Noudeh YJ. Health related quality of life in patients with Type 2 diabetes mellitus in Iran: A national survey. PLoS One. 2012;7(8):e44526. https://doi.org/10.1371/journal.pone.0044526 PMid:22952989

12. Schweyer L. Diabetes and quality of life. Rev Infirm. 2015;64(211):45-6.

13. Stefanović N, Radovanović RV, Đorđević AC, Stefanović N, Cvetković T. Quality of life in Type 2 diabetic patients. Acta Fac Med Naissensis. 2014;31(3):193-200.

14. Rwegerera GM, Moshomo T, Gaenamong M, Oyewo TA, Gollakota S, Rivera YP, et al. Health-related quality of life and associated factors among patients with diabetes mellitus in Botswana. Alexandria J Med. 2017;54(2):111-8.

15. Ningtyas DW, Wahyudi P, Prasetyowati I. Analyze Quality of Life in Patients with Type II Diabets Mellitus at Public Hospital of Bangil, Pasuruan; 2013. p. 1-7.

16. Saleh F, Ara F, Mumu SJ, Hafez MA. Assessment of healthrelated quality of life of Bangladeshi patients with Type 2 diabetes using the EQ-5D: A cross-sectional study. BMC Res Notes. 2015;8:497. https://doi.org/10.1186/s13104-015-1453-9 PMid:26420245

17. Sule AG, Odeigah LO, Alabi KM, Issa BA, Shittu RO, Joseph AI, et al. Quality of life of patients with tuberculosis in a Nigerian teaching hospital. Turk J Fam Med Prim Care. 2014;8(2):39. http://doi.org/10.5455/tjfmpc.46982

18. Martodiharjo S, Hakim L, Rasdianah N, Andayani TM. The description of medication adherence for patients of diabetes mellitus Type 2 in public health center Yogyakarta. Indones J Clin Pharm. 2017;5(4):249-57.

19. Feng $X$, Astell-Burt T. Impact of a Type 2 diabetes diagnosis on mental health, quality of life, and social contacts: A longitudinal study. BMJ Open Diabetes Res Care. 2017;5(1):e000198. http://doi.org/10.1136/bmjdrc-2016-000198 PMid:28243446

20. Sundaram M, Kavookjian J, Patrick JH, Miller LA, Madhavan SS, Scott VG. Quality of life, health status and clinical outcomes in Type 2 diabetes patients. Qual Life Res. 2007;16(2):165-77. http://doi.org/10.1007/s11136-006-9105-0 PMid:17033903

21. Al-Maskari MY, Al-Shookri AO, Al-Adawi SH, Lin KG. Assessment of quality of life in patients with Type 2 diabetes mellitus in Oman. Saudi Med J. 2011;32(12):1285-90. PMid:22159385

22. Ferrannini $E$ and Cushman WC. Diabetes and hypertension: The bad companions. Lancet. 2012;380(9841):601-10. http:// doi.org/10.1016/S0140-6736(12)60987-8 PMid:22883509

23. Laxy M, Knoll G, Schunk M, Meisinger C, Huth C, Holle R.
Quality of diabetes care in Germany improved from 2000 to 2007 to 2014, but improvements diminished since 2007. Evidence from the population-based KORA studies. PLoS One. 2016;11(10):e0164704. http://doi.org/10.1371/journal. pone. 0164704

PMid:27749939

24. Animaw W, Seyoum Y. Increasing prevalence of diabetes mellitus in a developing country and its related factors. PLoS One. 2017;12(11):e0187670. http://doi.org/10.1371/journal. pone.0187670

PMid:29112962

25. Curb JD. Effect of diuretic-based antihypertensive treatment on cardiovascular disease risk in older diabetic patients with isolated systolic hypertension. Systolic Hypertension in the Elderly Program Cooperative Research Group. JAMA. 2003;276(23):1886-92.

PMid:8968014

26. Turnbull F, Neal B, Algert C, Chalmers J, Chapman N, Cutler J, et al. Effects of different blood pressure-lowering regimens on major cardiovascular events in individuals with and without diabetes mellitus. Arch Intern Med. 2005;165(12):1410-9. https://doi.org/10.1001/archinte.165.12.1410 PMid:15983291

27. Unit $\mathrm{R}$, Hos $\mathrm{H}$. Effects of calcium-channel blockade in older patients with diabetes and systolic hypertension. N Engl J Med. 1999;340(9):677-84. https://doi.org/10.1056/ NEJM199903043400902

PMid: 10053176

28. Sun L, Yan B, Gao Y, Su D, Peng L, Jiao Y, et al. Relationship between blood pressure reverse dipping and Type 2 diabetes in hypertensive patients. Sci Rep. 2016;6(1):25053.

29. Smits KP, Sidorenkov G, Kleefstra N, Hendriks SH, Bouma M, Meulepas M, et al. Is guideline-adherent prescribing associated with quality of life in patients with Type 2 diabetes? PLoS One. 2018;13(8):e0202319. https://doi.org/10.1371/journal. pone.0202319 PMid:30114242

30. Vinik AI, Vinik EJ, Colberg SR, Morrison S. Falls risk in older adults with Type 2 diabetes. Clin Geriatr Med. 2015;31(1):89-99. https://doi.org/10.1016/j.cger.2014.09.002 PMid:25453303

31. Granado-Casas M, Martínez-Alonso M, Alcubierre N, RamírezMorros A, Hernández M, Castelblanco E, et al. Decreased quality of life and treatment satisfaction in patients with latent autoimmune diabetes of the adult. PeerJ. 2017;5:e3928. https:// doi.org/10.7717/peerj.3928 PMid:29062603

32. Wahyuni $\mathrm{Y}$, Nursiswati N, Anna A. Quality of life based on the characteristics of Type 2 diabetes mellitus patients. J Keperawatan Padjadjaran. 2014;2(1):25-34.

33. Pratita ND. Relationship of spouse support and health locus of control with adherence in following medication threatment among diabetes mellitus Type 2 patients. J IIm Mhs Univ Surabaya. 2012;1(1):1-24. 